\title{
PENGARUH SOSIALISASI DAN PEMAHAMAN PERATURAN MENTERI KEUANGAN NOMOR 86 TAHUN 2020 TERHADAP KEMAUAN MENJALANKAN KEWAJIBAN PERPAJAKAN PADA MASA COVID-19 (PADA UMKM ORANG PRIBADI SEKTOR PERDAGANGAN DI KUDUS)
}

\author{
Hasna Mudiarti, S.E., M.Ak. \\ Program Studi Akuntansi Fakultas Ekonomi Universitas Muhammadiyah Kudus \\ hasnamudiarti@umkudus.ac.id \\ Ulva Rizky Mulyani, S.E., M.Ak. \\ Program Studi Akuntansi Fakultas Ekonomi Universitas Muria Kudus \\ ulva.rizky@umk.ac.id
}

\begin{abstract}
ABSTRAK
Penelitian ini bertujuan untuk menguji pengaruh sosialisasi Peraturan Menteri Keuangan Nomor 86/PMK.03/2020 Tahun 2020 (insentif pajak untuk wajib pajak terdampak pandemi corona virus disease 2019) dan pemahaman wajib pajak atas Peraturan Menteri Keuangan Nomor 86/PMK.03/2020 Tahun 2020 terhadap kemauan wajib pajak dalam menjalankan kewajiban perpajakannya. Populasi dalam penelitian ini adalah pelaku UMKM orang pribadi sektor perdagangan di Kabupaten Kudus. Pengambilan sampel menggunakan metode purposive sampling, dengan jumlah sampel sebanyak 66 responden. Data yang diperoleh dianalisis dengan menggunakan teknik analisis PLS (Partial Least Square) melalui software SmartPLS. Hasil pengujian menunjukkan bahwa sosialisasi dan pemahaman PMK No.86 Tahun 2020 berpengaruh positif dan signifikan terhadap kemauan menjalankan kewajiban perpajakan UMKM orang pribadi sektor perdagangan di Kudus pada masa covid-19.
\end{abstract}

Kata Kunci: sosialisasi PMK Nomor 86 Tahun 2020, pemahaman PMK Nomor 86 Tahun 2020 , kemauan menjalakan kewajiban perpajakan.

\section{ABSTRACT}

This study aims to analyze the influence of the socialization of the Minister of Finance Regulation Number 86 / PMK.03 / 2020 of 2020 (tax incentives for taxpayers affected by the pandemic corona virus disease 2019) and the understanding of taxpayers on the Minister of Finance Regulation Number 86 / PMK.03 / 2020 of 2020 regarding the willingness of taxpayers to carry out their tax obligations. The population in this study were private SMEs in the trading sector in Kudus Regency. Sampling using purposive sampling method, with a sample size of 66 respondents. The obtained data were analyzed using the PLS (Partial Least Square) analysis technique through the SmartPLS software. The test results show that the socialization and the understanding of PMK No.86 of 2020 has a positive and significant effect on the willingness to carry out the tax obligations of private SMEs in the trading sector in Kudus during the covid-19 period.

Keywords: socialization of PMK Number 86 of 2020, understanding of PMK Number 86 of 2020, willingness to carry out tax obligations 


\section{PENDAHULUAN}

Pajak merupakan sumber penerimaan terbesar bagi negara yang digunakan untuk membiayai pengeluaran negara. Hal ini sesuai dengan fungsi pajak sebagai budgeter yaitu sumber dana yang diperuntukkan bagi pembiayaan pengeluaran-pengeluaran pemerintah, seperti dimasukkannya pajak dalam APBN sebagai penerimaan dalam negeri. Data Badan Pusat Statistik (BPS) menunjukkan bahwa realisasi penerimaan perpajakan terus mengalami peningkatan dengan mencapai angka 80\% dari total realisasi pendapatan (bps.go.id, 2020). Adapun realisasi pendapatan negara selama lima tahun terakhir tercermin pada gambar 1 berikut:

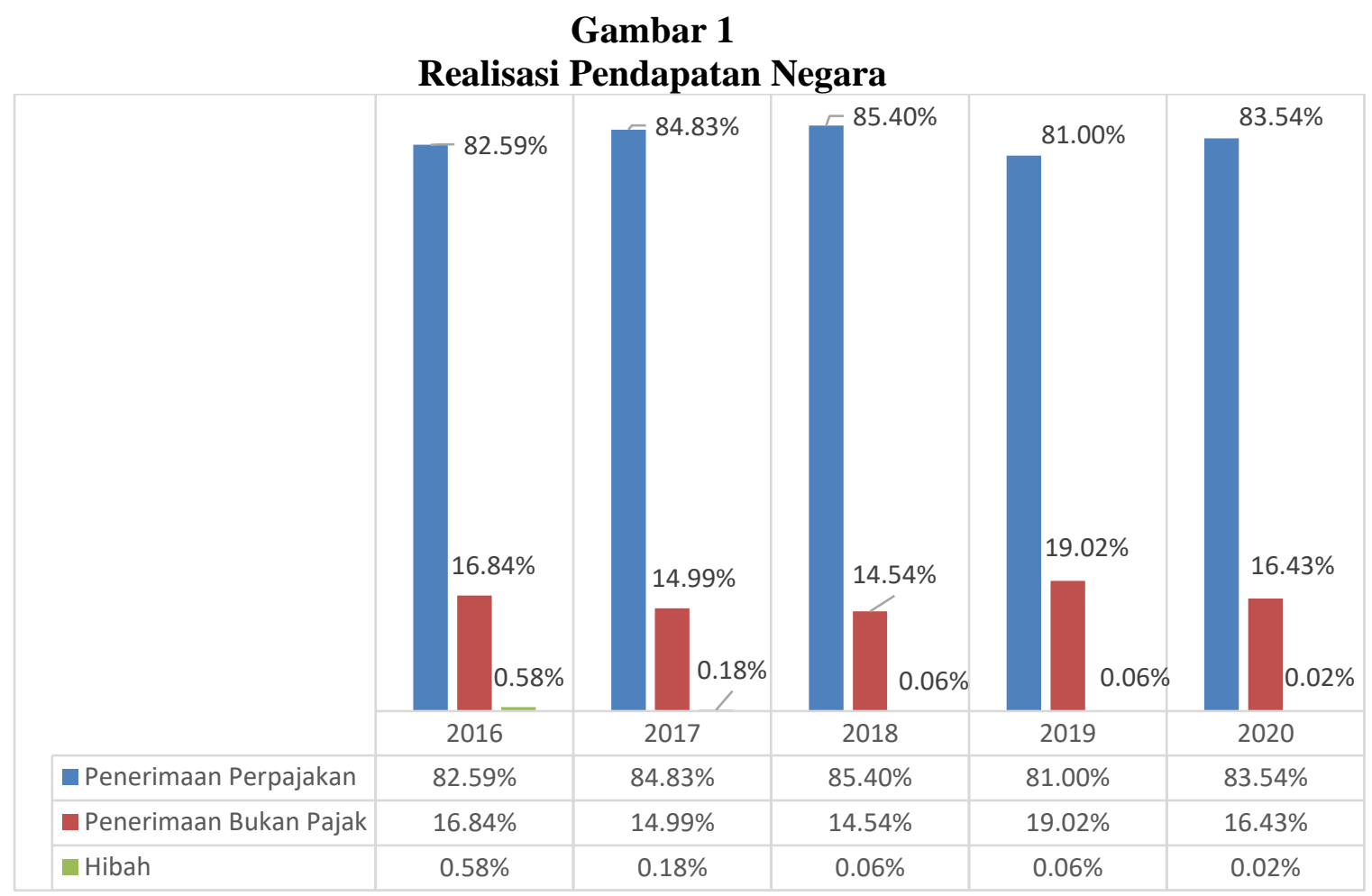

Sumber: https://www.bps.go.id/, Juni 2020

Berdasarkan gambar $1 \mathrm{di}$ atas dapat dilihat bahwa penerimaan perpajakan mengalami peningkatan yang cukup signifikan baik secara nominal maupun secara persentase terhadap seluruh pendapatan negara. Penerimaan perpajakan memiliki porsi terbesar dalam menyumbang penerimaan negara. Oleh karena itu, pemerintah terus mengupayakan peningkatan penerimaan pajak agar pembangunan negara dapat berjalan dengan lancar. 
Menurut Undang-Undang Nomor 20 Tahun 2008 tentang Usaha Mikro, Kecil dan Menengah (UMKM), usaha kecil didefinisikan sebagai kegiatan ekonomi produktif yang berdiri sendiri. Kegiatan usaha mikro, kecil, dan menengah ini di dirikan oleh perorangan atau badan usaha yang bukan bagian dari anak perusahaan atau bukan cabang perusahaan yang dimiliki atau menjadi bagian baik langsung maupun tidak langsung dari usaha menengah atau usaha besar serta memenuhi kriteria lain. Menurut Badan Perencanaan Pembangunan Nasional usaha mikro, kecil dan menengah memiliki kontribusi peranan cukup besar yaitu perluasan kesempatan kerja dan penyerapan tenaga kerja, pembentukan produk domestik bruto, dan penyediaan jarring pengaman terutama bagi masyarakat berpendapat rendah untuk menjalankan kegiatan ekonomi produktif. Kontribusi usaha mikro, kecil, dan menengah terhadap perekonomian Indonesia yaitu sebagai sarana memeratakan tingkat perekonomian rakyat kecil, sarana mengentaskan kemiskinan, dan sarana pemasukan devisa bagi negara.

Usaha Mikro, Kecil dan Menengah (UMKM) berperan besar dalam perekonomian nasional. Berdasarkan data Kementerian Koperasi dan Usaha Kecil Menengah (UKM) menunjukkan bahwa pada tahun 2020 tercatat jumlah unit UMKM mencapai sebesar 99,9\% dari total unit usaha di Indonesia dan UMKM menyerap 97,22\% dari total tenaga kerja negara. Usaha Mikro Kecil dan Menengah juga memiliki kontribusi besar terhadap penerimaan pajak tercatat pada tahun 2015 mencapai sebesar Rp 3,4 triliun, tahun 2016 sebesar Rp 4,4 triliun, tahun 2017 sebesar Rp 5,7 triliun dan di tahun 2018 sebesar Rp 5,8 triliun (pajak.go.id, 2020).

Namun kondisi UMKM sekarang ini sangat memprihatinkan. Sebanyak 47\% pelaku UMKM harus gulung tikar karena terdampak pandemic virus corona (Tempo, Jakarta). Pelaku UMKM terkendala dari sisi supply karena terganggunya distribusi selama masa pandemi Covid-19. Selain itu, pelemahan dari sisi permintaan semakin menekan keberlangsungan UMKM dalam negeri. Saat ini pertumbuhan perekonomian negara bernilai negatif atau mengalami resesi. Hal ini sebagai akibat dari pandemi corona virus Covid-19 yang terjadi sejak awal tahun 2020. Kondisi pandemi covid-19 tentunya sangat berdampak besar bagi ketahanan dan perekonomian UMKM di Indonesia.

Salah satu langkah pemerintah untuk meringankan beban ekonomi UMKM di bidang perpajakan pada masa pandemi covid-19 adalah dengan memberikan insentif pajak yaitu 
pajak penghasilan (PPh) final ditanggung pemerintah (DTP). Insentif pajak tersebut diatur dalam Peraturan Menteri Keuangan Nomor 86/PMK.03/2020 Tahun 2020 tentang insentif pajak untuk wajib pajak terdampak pandemi corona virus disease 2019. Pemberian insentif ini berlangsung dari bulan April sampai dengan Desember 2020. Pemerintah berhadarap dengan pemberian insentif pajak dapat menggerakkan roda perekonomian negara dan mestabilkan pertumbuhan ekonomi. Hal ini sesuai dengan fungsi pajak sebagai regulator untuk membantu masyarakat dalam hal ekonomi dan sosial.

Beberapa penelitian terdahulu terkait kebijakan fiskus untuk UMKM terbukti berpengaruh terhadap kemauan UMKM dalam menjalankan kewajiban perpajakan. Kemauan menjalankan kewajiban perpajakan merupakan suatu nilai dimana seseorang dengan sukarela membayar, melaporkan perpajakan yang digunakan untuk membiayai pengeluaran umum negara dengan tidak mendapat jasa timbal balik secara langsung (Nurlaela, 2013). Penelitian yang dilakukan oleh Ayem dan Nofitasari (2019) membuktikan bahwa sosialisasi Peraturan Pemerintah Nomor 23 Tahun 2018 berpengaruh postif dan signifikan terhadap kemauan membayar pajak. Pangesti dan Yushita (2019) dalam penelitiannya juga menyatakan bahwa pemahaman Peraturan Pemerintah Nomor 23 Tahun 2018 berpengaruh postif dan signifikan terhadap kemauan membayar pajak. Penelitian-penelitian tersebut mendukung hasil penelitian (Puspita. dkk, 2016) yang mengungkapkan bahwa sosialisasi dan pemahaman kebijakan sunset policy berpengaruh signifikan terhadap kemauan membayar pajak.

Berdasarkan pemaparan di atas, maka tujuan yang hendak dicapai dalam penelitian ini adalah untuk menguji secara empiris pengaruh soialisasi dan pemahaman Peraturan Menteri Keuangan Nomor 86 Tahun 2020 terhadap kemauan menjalankan kewajiban perpajakan UMKM di masa pandemi covid-19.

\section{TINJAUAN PUSTAKA}

\subsection{Landasan Teori}

\subsubsection{Teori Atribusi}

Teori atribusi menurut Heider (1958) didefinisikan bahwa perilaku seseorang ditentukan oleh kombinasi antara kekuatan internal dan kekuatan eksternal. Kekuatan internal adalah perilaku yang diyakini oleh kendali seorang individu, sedangkan kekuatan eksternal adalah perilaku yang berasal dari sebab-sebab luar. Pada penelitian ini teori atribusi 
digunakan untuk menjelaskan perilaku wajib pajak dalam menjalankan kewajiban perpajakannya yangmana dipengaruhi oleh faktor internal (pemahaman peraturan perpajakan) dan faktor eksternal (sosialisasi perpajakan).

\subsubsection{Kemauan Menjalankan Kewajiban Perpajakan}

Kemauan dalam Kamus Lengkap Bahasa Indonesia (2005) didefiniskan sebagai dorongan dari dalam yang sadar, berdasarkan pertimbangan pikir dan perasan, serta seluruh pribadi seseorang yang menimbulkan kegiatan yang terarah pada tercapainya tujuan tertentu yang berhubungan dengan kebutuhan hidupnya. Kemauan menjalankan kewajiban perpajakan merupakan suatu nilai dimana seseorang dengan sukarela membayar, melaporkan perpajakan yang digunakan untuk membiayai pengeluaran umum negara dengan tidak mendapat jasa timbal balik secara langsung (Nurlaela, 2013).

\subsubsection{Sosialisasi Perpajakan}

Sosialisasi dalam Kamus Lengkap Bahasa Indonesia (2005) diartikan sebagai upaya memasyarakatkan sesuatu sehingga menjadi dikenal, dipahami, dihayati oleh masyarakat. Menurut Wahono (2012) mendefinisikan sosialisasi perpajakan sebagai berikut: "Sosialisasi perpajakan adalah upaya yang dilakukan oleh dirjen pajak untuk memberikan sebuah pengetahuan kepada masyarakat dan khususnya wajib pajak agar mengetahui tentang segala hal mengenai perpajakan baik peraturan maupun tata cara perpajakan melalui metode-metode yang tepat". Sosialisasi perpajakan dapat disampaikan melalui berbagai media, seperti brosur, televisi, radio, koran, spanduk yang dipasang di jalan dan sosialisasi langsung yang diberikan oleh petugas pajak. Kegiatan sosialisasi perpajakan tersebut bermanfaat bagi wajib pajak untuk lebih mengerti tentang perpajakan yang dapat memudahkan wajib pajak dalam melaksanakan kewajiban perpajakannya.

\subsubsection{Pemahaman Perpajakan}

Pemahaman wajib pajak terhadap peraturan perpajakan adalah cara wajib pajak dalam memahami peraturan perpajakan yang telah ada (Pangesti dan Yushita, 2019). Pengetahuan dan pemahaman peraturan perpajakan merupakan penalaran dan penangkapan makna tentang peraturan perpajakan. Wajib pajak yang tidak memahami peraturan perpajakan secara jelas cenderung akan menjadi wajib pajak yang tidak taat (Hardiningsih dan Yulianawati, 2011). Semakin paham wajib pajak terhadap peraturan perpajakan, maka semakin paham pula wajib pajak kewajiban perpajakannya. 


\subsubsection{Peraturan Menteri Keuangan Nomor 86/PMK.03/2020}

Pandemi Corona Virus Disease 2019 merupakan bencana nasional yang mempengaruhi stabilitas ekonomi dan produktivitas masyarakat. Oleh karena itu, pemerintah memberikan insentif pajak untuk mendukung penanggulangan dampak Corona Virus Disease 2019 bagi UMKM. Insentif tersebut diatur dalam Peraturan Menteri Keuangan Nomor 86/PMK.03/2020 tentang insentif pajak untuk wajib pajak terdampak pandemi corona virus disease 2019 yang berlaku sejak bulan April sampai dengan Desember 2020.

Insentif pajak penghasilan (PPh) final diberikan kepada wajib pajak yang memiliki peredaran bruto tertentu sesuai dengan ketentuan sebagaimana dimaksud dalam Peraturan Pemerintah Nomor 23 Tahun 2018 yang dikenai PPh final sebesar 0,5\% (nol koma lima persen) dari jumlah peredaran bruto. Wajib pajak mengajukan permohonan surat keterangan UMKM terlebih dahulu kepada DJP atau yang dikenal surat keterangan PP 23/2018 melalui situs www.pajak.go.id. Wajib pajak harus menyampaikan laporan realisasi pemanfaat insentif $\mathrm{PPh}$ final ditanggung pemerintah (DTP) paling lambat tanggal 20 bulan berikutnya setelah masa pajak berakhir. Dalam menyampaikan laporan realisasi, wajib pajak mengunduh format dan jenis file laporan realisasi sesuai dengan insentif yang dimanfaatkan di laman www.pajak.go.id, tepatnya pada fitur 'e-Reporting Insentif Covid-19'. Laporan realisasi PPh final DTP meliputi penjabaran identitas wajib pajak serta PPh terutang atas penghasilan yang diterima atau diperoleh wajib pajak serta rekapitulasi peredaran bruto atas transaksi dengan pemotong atau pemungut pajak.

\subsection{Kerangka Pemikiran Teoritis}

Adapun kerangka pemikiran teoritis pada penelitian ini adalah sebagai berikut pada gambar 2:

\section{Gambar 2}

Kerangka Pemikiran Teoritis 


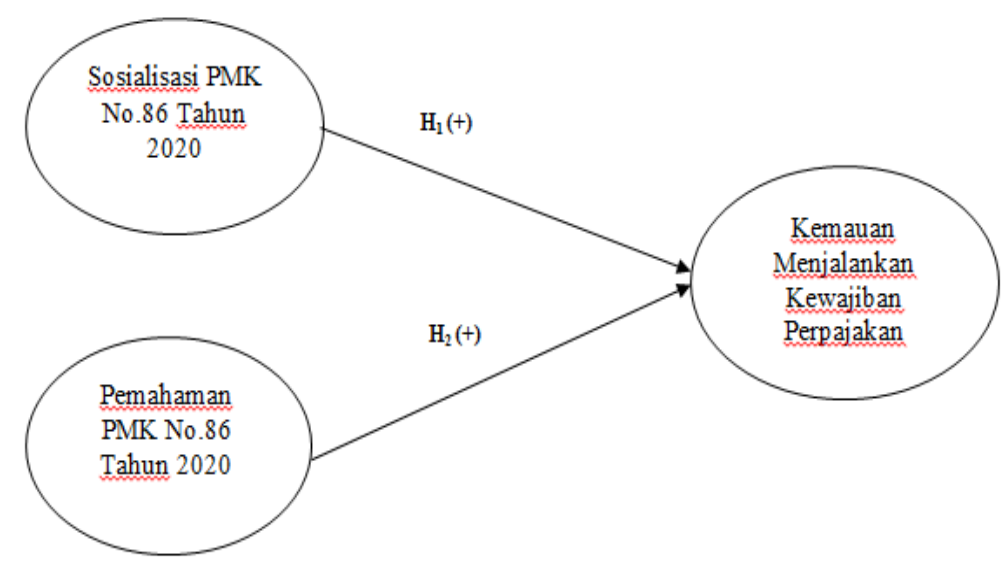

\subsection{Hipotesis Penelitian}

\subsubsection{Pengaruh Sosialisasi PMK Nomor 86 Tahun 2020 Terhadap Kemauan Menjalankan Kewajiban Perpajakan}

Sosialisasi PMK Nomor 86 Tahun 2020 merupakan sosialisasi perpajakan yang dilaksanakan oleh Direktorat Jenderal Pajak (DJP) baik melalui penyuluhan secara langsung oleh dirjen pajak maupun melalui media sosial. Sosialisasi ini bertujuan untuk memberikan informasi mengenai PMK Nomor 86 Tahun 2020 yang mengatur tentang insentif pajak penghasilan final yang terutang ditanggung oleh pemerintah bagi wajib pajak UMKM sesuai kriteria PP Nomor 23 Tahun 2018 yang terdampak pandemic corona virus disease 2019. Sosialisasi yang semakin gencar dan intensif akan menjadikan wajib pajak mengerti akan kewajiban perpajakannya sehingga bersedia untuk menjalankan kewajiban perpajakannya sesuai dengan peraturan perundang-undangan yang berlaku. Sa'diah, dkk (2019) dalam penelitiannya mengungkapkan bahwa sosialisasi pajak berpengaruh positif terhadap kemauan membayar pajak. Hal ini didukung oleh penelitian Ayem dan Nofitasari (2019) yang membuktikan bahwa sosialisasi PP Nomor 23 Tahun 2018 berpengaruh positif dan signifikan terhadap kemauan membayar pajak. Selain itu, penelitian Puspita, dkk (2016) juga mengungkapkan hal serupa yaitu sosialisasi kebijakan sunset policy mempunyai pengaruh yang signifikan dan positif terhadap kemauan membayar pajak. Berdasarkan uraian tersebut dapat dirumuskan hipotesis yang pertama dalam penelitian ini yaitu:

$\mathrm{H}_{1}$ : Sosialisasi PMK Nomor 86 Tahun 2020 berpengaruh posistif terhadap kemauan wajib pajak UMKM dalam menjalankan kewajiban perpajakannya 


\subsubsection{Pengaruh Pemahaman PMK No.86 Tahun 2020 Terhadap Kemauan Menjalankan Kewajiban Perpajakan}

Wajib pajak yang mengerti dan memahami sebuah peraturan maka akan melaksanakan peraturan tersebut selama tidak bersifat merugikan (Pangesti dan Yushita, 2019). Pemerintah memberikan insentif pajak yang diatur dalam Peraturan Menteri Keuangan Nomor 86 Tahun 2020 tentunya bertujuan untuk meringankan beban ekonomi wajib pajak UMKM dalam pemenuhan kewajiban perpajakannya. Insentif PPh final terutang diberikan kepada wajib pajak sesuai kriteria PP Nomor 23 Tahun 2018 yang terdampak pandemic corona virus disease 2019. Wajib mengajukan permohonan surat keterangan PP 23/2018 kepada DJP terlebih dahulu secara online setelah itu wajib pajak dapat memanfaatkan insentif PPh DTP tersebut. Peraturan yang mudah dipahami dan diterapkan, menjadikan wajib pajak bersedia untuk menjalankan kewajiban perpajakannya. Penelitian yang dilakukan oleh Ilkham dan Haryanto (2017) menyatakan bahwa pengetahuan dan pemahaman peraturan perpajakan berpengaruh postif terhadap kemauan membayar pajak. Puspita, dkk (2016) dalam penelitiannya juga membuktikan bahwa pemahaman kebijakan sunset policy berpenagruh positif dan signifikan terhadap kemauan membayar pajak. Berdasarkan uraian tersebut dapat dirumuskan hipotesis yang kedua dalam penelitian ini yaitu:

$\mathrm{H}_{2}$ : Pemahaman PMK Nomor 86 Tahun 2020 berpengaruh posistif terhadap kemauan wajib pajak UMKM dalam menjalankan kewajiban perpajakannya

\section{METODE PENELITIAN}

\subsection{Populasi dan Sampel}

Populasi dalam penelitian ini yaitu pelaku UMKM sektor perdagangan di Kabupaten Kudus. Teknik pengambilan sampel yang digunakan adalah metode Purposive Sampling dengan kriteria UMKM yang termasuk dalam PP Nomor 23 Tahun 2020 yaitu yang dikenai PPh final sebesar 0,5\% (nol koma lima persen) dari jumlah peredaran bruto. Jumlah sampel pada penelitian ini sebanyak 66 responden.

\subsection{Jenis Dan Sumber Data}

Pada penelitian ini menggunakan data primer yang diperoleh dari penyebaran kuesioner kepada responden. Jawaban responden direkapitulasi oleh peneliti untuk dianalisis sehingga didapatkan jawaban dari pertanyaan penelitian. 


\subsection{Metode Analisis}

Penelitian ini dianalisis menggunakan menggunakan metode analisis Partial Least Square (PLS) dengan menggunakan software SmartPLS yang meliputi evaluasi model pengukuran (outer model), evaluasi model struktural (inner model) dan pengujian hipotesis. Evaluasi model pengukuran atau outer model dilakukan untuk menilai validitas dan realibilitas dari indikator-indikator pembentuk kontruk laten. Sedangkan evaluasi model struktural atau inner model bertujuan memprediksi hubungan antar variabel laten dengan melihat besar variance yang dapat dijelaskan dan untuk mengetahui signifikansi dari $P$-value. Presentase variance dengan melihat $R$-Squares utuk setiap variabel laten endogen sebagai kekuatan prediksi dari model struktural. Nilai R-Squares digunakan untuk menjelaskan pengaruh variabel laten eksogen tertentu terhadap variabel endogen apakah mempunyai pengaruh yang substansive.

Pengujian hipotesis dalam model ini mengenai hubungan antara variabel laten eksogen dan endogen yaitu menggunakan besaran nilai t-statistics dan p-value. Nilai $t$ statistics $>1,96$ dan $p$-value $<0,05$ dikatakan signifikan pada alpha 5\% yang berarti hipotesis diterima pada alpha 5\%. Sedangkan nilai $t$-statistics $<1,96$ dan $\mathrm{p}$-value $>0,05$ dikatakan tidak signifikan pada alpha 5\% yang berarti hipotesis ditolak pada alpha 5\% (Ghozali, 2014).

\section{HASIL PENELITIAN DAN PEMBAHASAN}

\subsection{Pengujian Model Pengukuran}

Adapun model pengukuran untuk uji validitas dan reliabilitas, koefisien determinasi model dan koefisien jalur untuk model persamaan dapat dilihat pada gambar 3 berikut:

Gambar 3

Tampilan Hasil PLS Algorithm 


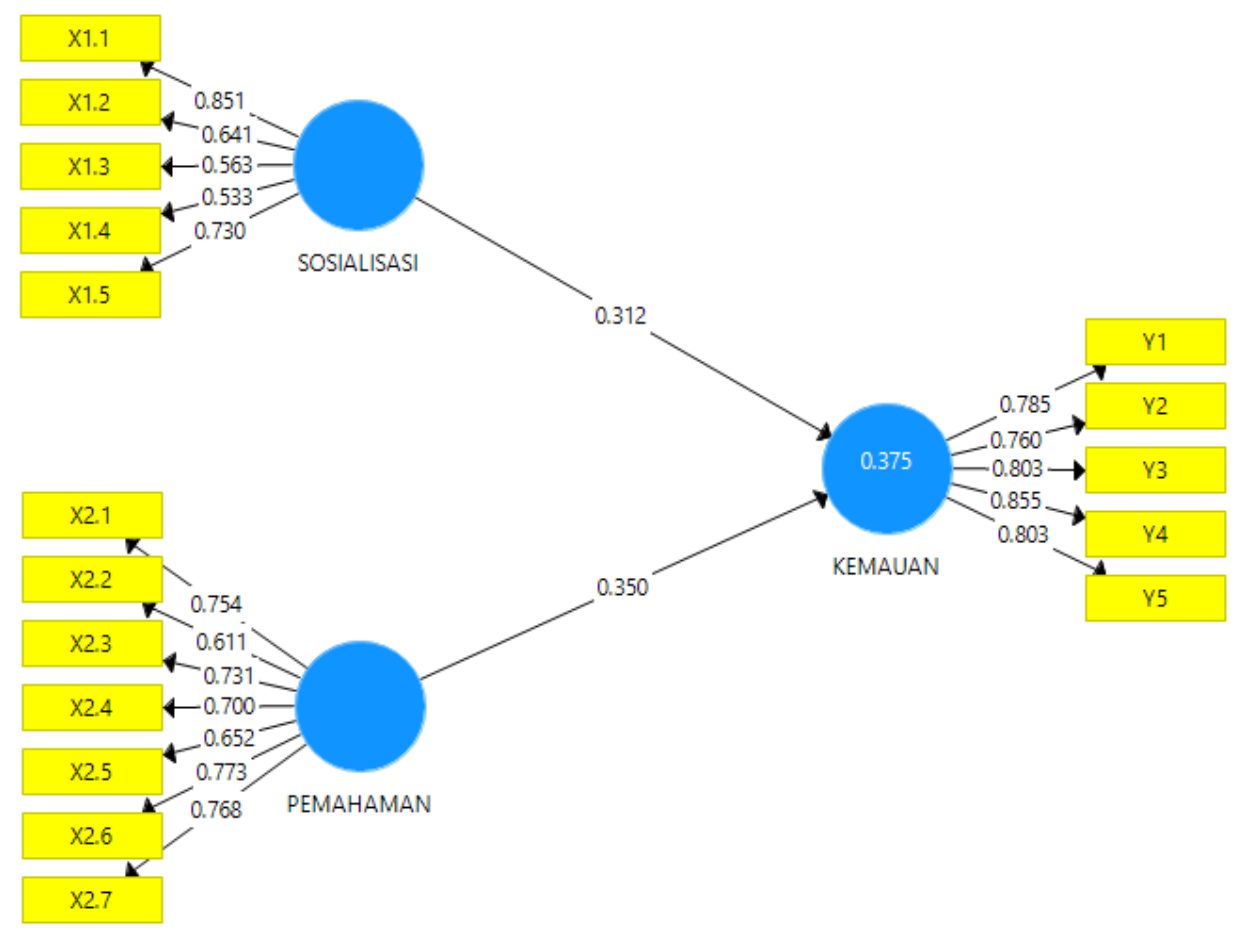

Gambar 3 Tampilan output model pengukuran, 2020.

\subsubsection{Hasil Uji Validitas Konvergen}

Hasil uji validitas konvergen dilihat dari nilai loading factor untuk tiap indikator konstruk. Nilai loading factor harus lebih besar 0,7 untuk penelitian yang bersifat confirmatory dan untuk penelitian yang bersifat exploratory nilai loading factor sebesar 0,50,6 masih dapat diterima. Penelitian ini merupakan penelitian exploratory, maka nilai loading factor 0,5-0,6 dianggap cukup valid. Nilai loading factor seluruh indikator yang digunakan dalam penelitian terlihat pada tabel 1 berikut ini:

Tabel 1

Nilai Outer Model (Outer Loading)

\begin{tabular}{|l|l|l|}
\hline Variabel & Indikator & Outer Loading \\
\hline Sosialisasi (X1) & X1.1 & 0,851 \\
\cline { 2 - 3 } & X1.2 & 0,641 \\
\cline { 2 - 3 } & X1.3 & 0,563 \\
\cline { 2 - 3 } & X1.4 & 0,533 \\
\cline { 2 - 3 } & X1.5 & 0,730 \\
\hline Pemahaman (X2) & X2.1 & 0,754 \\
\cline { 2 - 3 } & X2.2 & 0,611 \\
\cline { 2 - 3 } & X2.3 & 0,731 \\
\cline { 2 - 3 } & X2.4 & 0,700 \\
\cline { 2 - 3 } & X2.5 & 0,652 \\
\hline
\end{tabular}




\begin{tabular}{|c|c|c|}
\hline & $\mathrm{X} 2.6$ & 0,773 \\
\hline & $\mathrm{X} 2.7$ & 0,768 \\
\hline \multirow{4}{*}{$\begin{array}{l}\text { Kemauan Menjalankan } \\
\text { Kewajiban Perpajakan (Y) }\end{array}$} & Y.1 & 0,785 \\
\hline & Y.2 & 0,760 \\
\hline & Y.3 & 0,803 \\
\hline & Y.4 & 0,855 \\
\hline
\end{tabular}

Sumber: Data primer diolah, 2020.

Berdasarkan tabel 1 di atas, dapat dilihat bahwa nilai loading factor untuk tiap indikator konstruk $>0,5$. Hal tersebut menunjukkan bahwa semua indikator telah memenuhi syarat validitas konvergen.

\subsubsection{Hasil Uji Validitas Diskriminan}

Pengujian validitas diskriminan dilakukan untuk membuktikan apakah indikator pada suatu konstruk mempunyai loading factor terbesar pada konstruk yang dibentuknya daripada loading factor dengan konstruk yang lain, sebagaimana tersaji pada tabel 2 sebagai berikut:

Tabel 2

Cross Loading

\begin{tabular}{|c|c|c|c|}
\hline${ }_{\text {ariabel }} \mathrm{V}$ & Y & $1^{\mathrm{X}}$ & 2 \\
\hline${ }_{1.1}^{\mathrm{Y}}$ & $785^{0,}$ &, $429^{0}$ &, $452^{0}$ \\
\hline $1.2^{\mathrm{Y}}$ & $760^{0,}$ & $\begin{array}{r}0 \\
, 362\end{array}$ &, $539^{0}$ \\
\hline $1.3^{\mathrm{Y}}$ & $803^{0,}$ &, $357^{0}$ &, $321^{0}$ \\
\hline $1.4^{\mathrm{Y}}$ & $855^{0,}$ & $\begin{array}{r}0 \\
.580^{0}\end{array}$ &, $573^{0}$ \\
\hline $1.5^{\mathrm{Y}}$ & $803^{0,}$ & $\begin{array}{r}0 \\
, 471\end{array}$ & \\
\hline${ }_{1.1} \mathrm{X}$ & $491^{0,}$ &, $851^{0}$ & ${ }^{2}, 613^{0}$ \\
\hline $1.2^{X}$ & $291^{0,}$ &, $641^{0}$ & ,568 \\
\hline $1.4^{X}$ & 350 , &,${ }_{, 533}^{0}$ &, $339^{0}$ \\
\hline $1.5^{\mathrm{X}}$ & $369^{0,}$ &, $730^{0}$ & ,268 \\
\hline${ }_{2.1}^{X}$ & $536^{0,}$ &, $463^{0}$ &, $754^{0}$ \\
\hline $2.2^{X}$ & $318^{0,}$ &, $423^{0}$ &, $611^{0}$ \\
\hline & 0, & 0 & 0 \\
\hline
\end{tabular}




\begin{tabular}{|c|c|c|c|}
\hline 2.3 & 329 & ,577 & ,731 \\
\hline $2.4^{X}$ & $386^{0,}$ & ${ }^{6} 691^{0}$ &, $700^{0}$ \\
\hline $2.5^{\mathrm{X}}$ & $272^{0,}$ &, $389^{0}$ &, $652^{0}$ \\
\hline $2.6^{X}$ & $515^{0,}$ &, $490^{0}$ &, $773^{0}$ \\
\hline $2.7^{X}$ & $385^{0,}$ &, $559^{0}$ &, $768^{0}$ \\
\hline
\end{tabular}

Sumber: Data primer diolah, 2020.

Berdasarkan tabel 2 di atas dapat dilihat bahwa nilai korelasi indikator terhadap konstruknya lebih tinggi dibandingkan nilai korelasi indikator dengan konstruk lainnya. Oleh karena itu, tabel 2 di atas menunjukkan nilai cross loading dan adanya discriminate validity yang baik.

\subsubsection{Hasil Uji Reliabilitas}

Uji reliabilitas dilakukan dengan melihat nilai cronbach's alpha dan composite reliability dari blok indikator yang mengukur konstruk. Hasil pengujian nilai composite reliability dan cronbach's alpha tersebut seperti tersaji dalam tabel 3 berikut ini:

Tabel 3

Composite Reliability dan Cronbach's Alpha

\begin{tabular}{|c|c|c|}
\hline VARIABEL & $\begin{array}{c}\text { Cro } \\
\text { nbach's } \\
\text { Alpha } \\
\end{array}$ & $\begin{array}{c}\text { Co } \\
\text { mposite } \\
\text { Reliability }\end{array}$ \\
\hline $\begin{array}{ccc}\text { Kemauan } & \text { Menjalankan } & \text { Kewajiban } \\
\text { Perpajakan }(Y) & & \end{array}$ & $2^{0,86}$ & $00^{0,9}$ \\
\hline Sosialisasi PMK No.86 Tahun 2020 (X1) & $2^{0,84}$ & $79^{0,8}$ \\
\hline Pemahaman PMK No.86 Tahun 2020 (X2) & $5^{0,68}$ & $01^{0,8}$ \\
\hline
\end{tabular}

Sumber: Data primer diolah, 2020.

Hasil uji tabel 3, menunjukkan bahwa nilai composite reliability semua konstruk memiliki nilai >0,70 dan nilai cronbach's alpha >0,60, sehingga dapat disimpulkan bahwa model dalam penelitian ini telah memenuhi persyaratan reliabilitas.

\subsection{Pengujian Model Struktural (Inner Model)}

Model struktural dievaluasi menggunakan $R$-Squares untuk variabel endogen dan nilai koefisien path untuk variabel independen yang kemudian dinilai signifikansinya berdasarkan $t$-statistic setiap path. Adapun model struktural penelitian ini dapat dilihat pada gambar 4 berikut: 


\section{Gambar 4 \\ Tampilan Hasil PLS Boothstrapping}

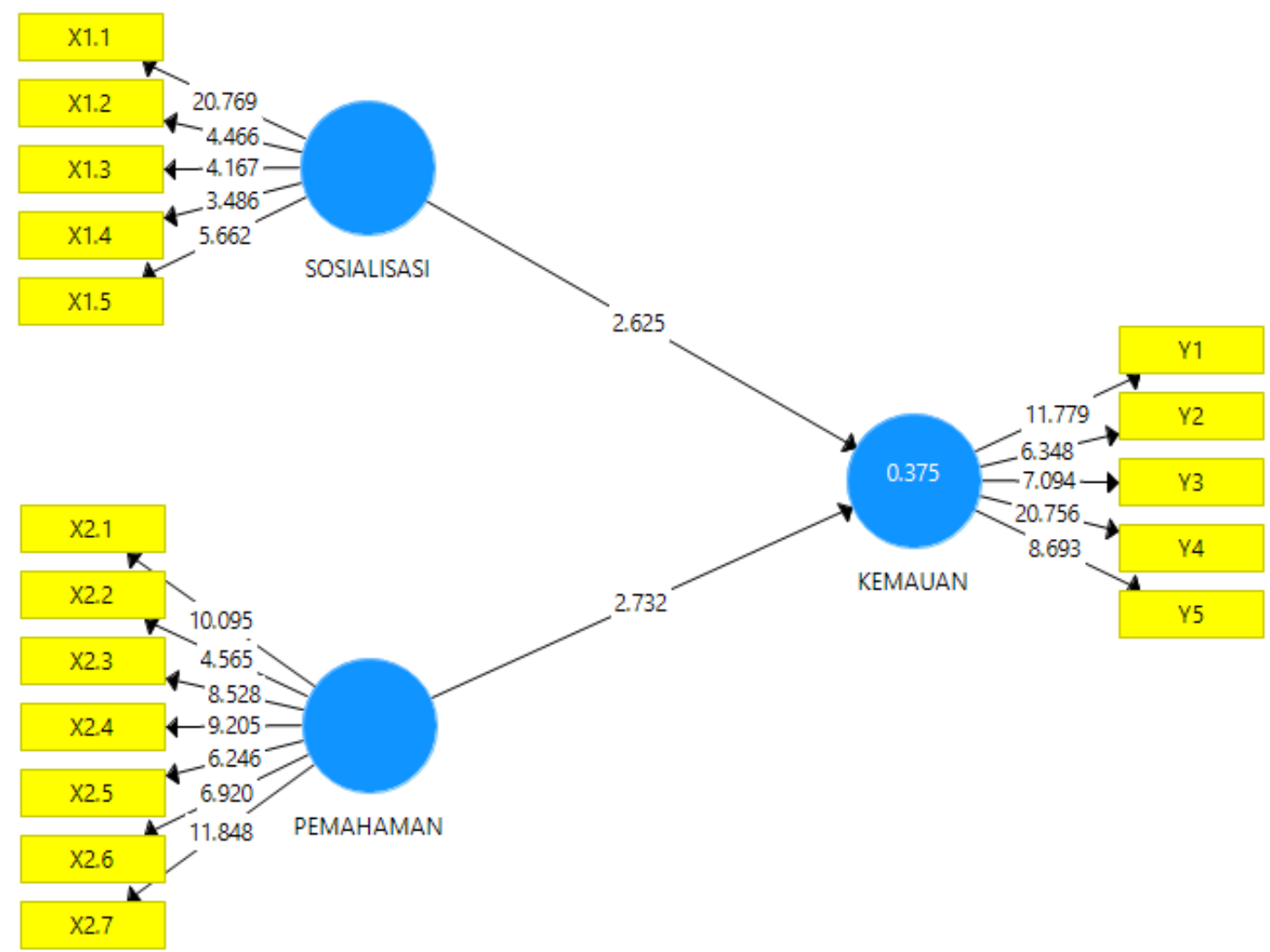

Gambar 4 tampilan output model struktural, 2020.

Dari gambar di atas, dapat dilihat nilai $R$-Squares sebesar 0,375 yang artinya bahwa $37,5 \%$ variabel kemauan menjalankan kewajiban perpajakan dijelaskan oleh variabel sosialisasi dan pemahaman PMK No.86 Tahun 2020, sedangkan sisanya dijelaskan oleh variabel lain yang tidak dijelaskan pada penelitian ini.

\subsection{Pengujian Hipotesis}

Pengujian hipotesis dianalisa dengan membandingkan nilai $t$-statistic yang dihasilkan dari output PLS dengan nilai t-tabel. Nilai p-value digunakan dalam menerima dan menolak hipotesis, taraf signifikansi $<0,05$ dan nilai tabel $>1,962$ maka hipotesis diterima (Ghozali, 2014). Hasil pengujian hipotesis dapat dilihat dari nilai $t$-statistic antara variabel independen ke variabel dependen dalam tabel Path Coefficient pada output SmartPLS dibawah ini: 
Tabel 4

Path Coefficients (Mean, STDEV, t-Value)

\begin{tabular}{|c|c|c|c|c|c|}
\hline & $\begin{array}{l}\text { Origin } \\
\text { al Sample } \\
\text { Estimate }\end{array}$ & $\begin{array}{c}\text { Sam } \\
\text { ple Mean }\end{array}$ & $\begin{array}{l}\text { Sta } \\
\text { ndard } \\
\text { Deviation }\end{array}$ & $\begin{array}{r}T- \\
\text { Statistics }\end{array}$ & mpulan $^{\text {Kesi }}$ \\
\hline $1 \rightarrow Y^{X}$ & 0,312 & 0,31 & 0,11 & 2,62 & $\begin{array}{c}\mathrm{H} 1 \\
\text { diterima }\end{array}$ \\
\hline $2 \rightarrow Y^{X}$ & 0,350 & 0,38 & 0,12 & 2,73 & $\begin{array}{c}\mathrm{H} 2 \\
\text { diterima }\end{array}$ \\
\hline
\end{tabular}

Sumber: Data primer diolah, 2020.

\subsection{Pembahasan}

\subsubsection{Pengaruh Sosialisasi PMK No.86 Tahun 2020 Terhadap Kemauan Menjalankan Kewajiban Perpajakan}

Berdasarkan hasil pengujian hipotesis pertama, diperoleh nilai t-statistic 2,625 $>1,962$ dan nilai original sample estimate positif sebesar 0,312. Hal tersebut menunjukkan bahwa hipotesis pertama diterima. Temuan ini juga mendukung teori atribusi yang menyatakan bahwa perilaku seseorang dipengaruhi oleh kekuatan eksternal. Pada penelitian ini membuktikan bahwa kemauan menjalankan kewajiban perpajakan pelaku UMKM pada masa covid-19 dipengaruhi oleh sosialisasi PMK No.86 Tahun 2020. Sosialisasi yang intensif terkait peraturan perpajakan menjadikan wajib pajak mengerti kewajiban perpajakannya. Sosialisasi tersebut mendorong wajib pajak untuk mau menjalankan kewajiban perpajakannya sesuai dengan peraturan perundang-undangan yang berlaku.

Hasil penelitian ini mendukung penelitian yang dilakukan oleh Puspita, dkk (2016) yang menyatakan bahwa sosialisasi kebijakan sunset policy berpengaruh positif terhadap kemauan membayar pajak. Selain itu juga mendukung penelitian Ayem dan Nofitasari (2019) yang membuktikan bahwa sosialisasi Peraturan Pemerintah No.23 Tahun 2018 berpengaruh positif dan signifikan terhadap kemauan membayar pajak wajib pajak UMKM.

\subsubsection{Pengaruh Pemahaman PMK No.86 Tahun 2020 Terhadap Kemauan Menjalankan Kewajiban Perpajakan}

Berdasarkan hasil pengujian hipotesis kedua, diperoleh nilai t-statistic 2,732>1,962 dan nilai original sample estimate positif sebesar 0,350. Hal tersebut menunjukkan bahwa hipotesis kedua diterima. Temuan ini juga mendukung teori atribusi yang menyatakan bahwa perilaku seseorang dipengaruhi oleh kekuatan internal. Pada penelitian ini membuktikan 
bahwa kemauan menjalankan kewajiban perpajakan pelaku UMKM pada masa covid-19 dipengaruhi oleh pemahaman PMK No.86 Tahun 2020. Wajib pajak yang memahami peraturan perpajakan yang berlaku, maka cenderung taat mau menjalankan kewajiban perpajakannya. Apalagi peraturan ini bertujuan untuk meringankan beban wajib pajak yang terdampak virus corona. Tentunya wajib pajak UMKM sangat antusias dalam menjalankan kewajiban perpajakan di masa covid-19.

Hasil penelitian ini mendukung penelitian yang dilakukan oleh Puspita, dkk (2016) yang menyatakan bahwa pemahaman kebijakan sunset policy berpengaruh positif terhadap kemauan membayar pajak. Selain itu juga mendukung penelitian Pangesti dan Yushita (2019) yang membuktikan bahwa pemahaman Peraturan Pemerintah No.23 Tahun 2018 berpengaruh positif dan signifikan terhadap kemauan membayar pajak.

\section{KESIMPULAN}

Hasil pengujian hipotesis disimpulkan bahwa sosialisasi dan pemahaman PMK No.86 Tahun 2020 berpengaruh positif dan signifikan terhadap kemauan menjalankan kewajiban perpajakan di masa covid-19. Nilai $R$-Squares diperoleh sebesar 0,375 yang artinya kemauan menjalankan kewajiban perpajakan di masa covid-19 dipengaruhi oleh sosialisasi dan pemahaman PMK No.86 Tahun 2020 sebesar 37,5\%, sedangkan sisanya dipengaruhi oleh variabel lain yang tidak digunakan dalam penelitian ini.

\section{SARAN}

Penelitian yang akan datang dapat lebih mengembangkan penelitian ini dengan menambahkan variabel independen yang lain, baik faktor internal maupun eksternal yang dapat mempengaruhi kemauan menjalankan kewajiban perpajakan. Selain itu, juga dapat memperluas populasi penelitian sehingga didapatkan hasil penelitian yang lebih maksimal.

\section{DAFTAR PUSTAKA}

Ayem, S., \& Nofitasari, D. (2018). Pengaruh Sosialisasi Pp No. 23 Tahun 2018, Modernisasi Sistem Administrasi Perpajakan, Dan Biaya Kepatuhan Terhadap Kemauan Membayar Pajak Pada Pada Wajib Pajak Umkm. Akuntansi Dan Governance Andalas, 2(23), 105121.

Ghozali, I. 2014. Structural Equation Modeling, Metode Alternatif dengan Partial Least Square (PLS). Edisi 4. Semarang: Badan Penerbit Universitas Diponegoro. 
Hardiningsih, P., \& Yulianawati, N. (2011). Faktor-Faktor Yang Mempengaruhi Kemauan Membayar Pajak. Dinamika Keuangan Dan Perbankan, 3(1), 126-142. https://doi.org/ISSN: 1979-4878.

Heider, F. 1958. The Pscychology of Interpersonal Relations. London: John Wiley \& Sons. Ilkham, M. (2017). Faktor-Faktor Yang Mempengaruhi Kemauan. Diponegoro Journal Of Accounting, 6, 1-9.

Nurlaela, S. (2013). Pengaruh Pengetahuan dan Pemahaman, Kesadaran, Persepsi Terhadap Kemauan Membayar Pajak Wajib Pajak Orang Pribadi Yang Melakukan Pekerjaan Bebas. Jurnal Paradigma, 11(16930827), 89-101.

Pangesti, D. M., \& Yushita, A. N. (2019). Pengaruh Kesadaran Membayar Pajak, Persepsi Atas Efektivitas Sistem Perpajakan, Dan Pemahaman Peraturan Pemerintah Nomor 23 Tahun 2018 Terhadap Kemauan Membayar Pajak (Pada Umkm Sektor Perdagangan Di Kabupaten Klaten). Nominal: Barometer Riset Akuntansi Dan Manajemen, 8(2), 166178. https://doi.org/10.21831/nominal.v8i2.26461

Peraturan Menteri Keuangan Nomor 86 Tahun 2020 tentang insentif pajak untuk wajib pajak terdampak pandemic corona virus disease 2019.

Puspita, Dian, A., Harimurti, F., \& Astuti, D. S. P. (2016). Pengaruh Sosialisasi dan Pemahaman Kebijakan Sunset Policy Terhadap Kemauan Membayar Pajak (Studi Kasus Pada Wajib Pajak Badan di KPP Pratama Surakarta). Jurnal Akuntansi Dan Sistem Teknologi Informasi, 12(No.4), 389-397.

Sa'idah, N., Sari, R. N., \& Ratnawati, V. (2019). Faktor-Faktor Yang Mempengaruhi Kemauan Membayar Pajak (Studi Empiris Wajib Pajak Orang Pribadi Non Karyawan). Jurnal Akuntansi, 7(2), 172-184.

Tempo.co.2020. 47 Persen UMKM Bangkrut Akibat Pandemi. 20 Mei. Jakarta.

Wahono, Sugeng. 2012. Mengurus Pajak Itu Mudah. PT. Elex Media. Jakarta. 